\title{
Combined toxicity and underlying mechanisms of a mixture of eight heavy metals
}

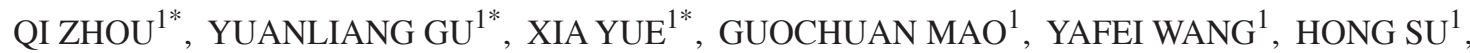 \\ JIN XU ${ }^{1}$, HONGBO SHI $^{1}$, BAOBO ZOU $^{1}$, JINSHUN ZHAO ${ }^{1}$ and RENYUAN WANG ${ }^{1,2}$ \\ ${ }^{1}$ Department of Preventative Medicine, Zhejiang Provincial Key Laboratory of Pathological and \\ Physiological Technology, Medical School of Ningbo University, Ningbo, Zhejiang 315211; \\ ${ }^{2}$ Ningbo Health and Family Planning Commission, Ningbo, Zhejiang 315010, P.R. China
}

Received November 28, 2015; Accepted November 15, 2016

DOI:10.3892/mmr.2016.6089

\begin{abstract}
With the rapid development of modernization and industrialization in China, a large quantity of heavy metals, including zinc, copper, lead, cadmium and mercury, have been entering the atmosphere, soil and water, the latter being the primary route of pollution. In the present study, in vitro experiments were performed to examine the joint toxicity and the underlying mechanisms of the eight most common heavy metals contaminating offshore waters on the eastern coast of Ningbo region. Using a cell cycle assay, cell apoptosis and reactive oxygen species (ROS) detection methods, the present study demonstrated that the heavy metal mixture arrested JB6 cells at the S phase, induced the generation of ROS and cell apoptosis. A luciferase assay indicated that the levels of activator protein-1 and nuclear factor $-\kappa B$ transcription factors were upregulated. Upregulation of the protein levels of C-jun and p65 were detected in the JB6 cells by western blot analysis; these two genes have important roles in cell carcinogenesis. These results provide a useful reference for further investigations on the combined toxicity of the exposure to multiple heavy metals.
\end{abstract}

\section{Introduction}

Heavy metals, including zinc, copper, cadmium, lead, chromium, mercury and nickel, are widely used in industry (1).

Correspondence to: Professor Jinshun Zhao or Professor Renyuan Wang, Department of Preventative Medicine, Zhejiang Provincial Key Laboratory of Pathological and Physiological Technology, Medical School of Ningbo University, 818 Fenghua Road, Jiangbei, Ningbo, Zhejiang 315211, P.R. China

E-mail: zhaojinshun@nbu.edu.cn

E-mail: wangry66@126.com

*Contributed equally

Key words: heavy metals, joint toxicity, apoptosis, JB6 cells, reactive oxygen species
Cadmium enters the human body primarily through food and water. By binding with thiol proteins in the body, cadmium can inhibit the activity of enzymes (2). Epidemiological data indicate that the joint pollution of lead and cadmium can increase the incidence and mortality rates of cardiovascular diseases (3). Experimental results have shown that joint treatment with low doses of lead and cadmium induces high blood pressure (4-6), with cadmium having a synergistic effect on the high blood pressure induced by lead $(7,8)$. These findings indicate that lead and cadmium have synergistic effects in toxicity $(9,10)$. Nickel can cause lung cancer in humans, which is classified by the International Agency for Research on Cancer as a 'group 1' carcinogen (11). Heavy metals can pollute water, air and soil (12). The most important route of contamination is water. Heavy metals are usually difficult to degrade in the environment, which results in them readily accumulating in plants and aquatic organisms. Heavy metals in contaminated water accumulate in a stepwise manner in algae, shellfish and fish, and finally reach the human body through the food chain (13-16). Therefore, the enrichment of multiple heavy metals in aquatic products or foods, including vegetables, is considered to be a health threat in China $(17,18)$. At present, there have been no investigations on the combined toxic effects of multiple heavy metals at levels mimicking those contaminating water or through food exposure.

Ningbo is a city on the eastern coast of China. Residents in the Ningbo region are accustomed to consuming aquatic products, particularly marine foods (19), leading to the rapid development of offshore aquaculture and marine farming in previous years. In the present study, eight of the most common heavy metals contaminating the offshore waters off the eastern coast of Ningbo were examined, including lead, cadmium, mercury, copper, zinc, manganese, nickel and chromium. These eight metals were selected for preparation as a mixture, with the proportions matching those found in the region of contamination, in order to investigate their joint toxicity and underlying mechanisms of multi-heavy metal exposure.

\section{Materials and methods}

Materials. Chemical compounds for the eight heavy metals, including $\left(\mathrm{CH}_{3} \mathrm{COO}\right)_{2} \mathrm{~Pb} \cdot 3 \mathrm{H}_{2} \mathrm{O}, \mathrm{CdCl}_{2} \cdot 2.5 \mathrm{H}_{2} \mathrm{O}, \mathrm{NiCl}_{2} \cdot 6 \mathrm{H}_{2} \mathrm{O}$, 
Table I. Preparation of the heavy metal mixture.

\begin{tabular}{lclc}
\hline Heavy metal & $\begin{array}{c}\text { Concentration in surface } \\
\text { water }(\mu \mathrm{g} / \mathrm{l})^{\mathrm{a}}\end{array}$ & $\begin{array}{c}\text { Compound used for } \\
\text { heavy metal }\end{array}$ & $\begin{array}{c}\text { Concentration in stock } \\
\text { solution }(\mathrm{mg} / \mathrm{l})\end{array}$ \\
\hline $\mathrm{Cu}$ & 2.05 & $\mathrm{CuSO}_{4} \cdot 5 \mathrm{H}_{2} \mathrm{O}$ & 2.05 \\
$\mathrm{~Pb}$ & 2.5 & $\left(\mathrm{CH}_{3} \mathrm{COO}\right)_{2} \mathrm{~Pb} \cdot 3 \mathrm{H}_{2} \mathrm{O}$ & 2.5 \\
$\mathrm{Cd}$ & 0.15 & $\mathrm{CdCl}_{2} \cdot 2.5 \mathrm{H}_{2} \mathrm{O}$ & 0.15 \\
$\mathrm{Zn}$ & 13.2 & $\mathrm{ZnSO}_{4} \cdot 7 \mathrm{H}_{2} \mathrm{O}$ & 13.2 \\
$\mathrm{Hg}$ & 0.033 & $\mathrm{CH}_{3} \mathrm{ClHg}_{2}$ & 0.033 \\
$\mathrm{Cr}$ & 0.3 & $\mathrm{~K}_{2} \mathrm{Cr}_{2} \mathrm{O}_{7}$ & 0.3 \\
$\mathrm{Mn}$ & 5 & $\mathrm{MnCl}_{2} \cdot 4 \mathrm{H}_{2} \mathrm{O}$ & 5 \\
$\mathrm{Ni}$ & 2 & $\mathrm{Cl}_{2} \mathrm{H}_{12} \mathrm{NiO}_{6}$ & 2 \\
$\mathrm{Notal}$ & 25.233 & $\mathrm{~N}_{\mathrm{A}}$ & 25.233 \\
\hline
\end{tabular}

a Surface water in Ningbo region.

$\mathrm{MnCl}_{2} \cdot 4 \mathrm{H}_{2} \mathrm{O}, \mathrm{ZnSO}_{4} \cdot 7 \mathrm{H}_{2} \mathrm{O}, \mathrm{CuSO}_{4} \cdot 5 \mathrm{H}_{2} \mathrm{O}, \mathrm{K}_{2} \mathrm{Cr}_{2} \mathrm{O}_{7}$ and $\mathrm{CH}_{3} \mathrm{ClHg}$ (all analytical reagents) were purchased from Sinopharm Chemical Reagent Beijing Co. Ltd. (Beijing, China). Dulbecco's modified Eagle's medium (DMEM), heat-inactivated newborn calf serum (NCS), Tris-EDTA , $0.5 \%$ Trypsin-EDTA and propidium iodide (PI) were obtained from Thermo Fisher Scientific, Inc. (Waltham, MA, USA). Hoechst 33342, 2',7'-dichlorodihydrofluorescein diacetate ( $\mathrm{H}_{2}$ DCFDA) and dihydroethidium (DHE) were purchased from Molecular Probes (Eugene, OR, USA). An Annexin V-fluorescein isothiocyanate (FITC)/PI apoptosis detection kit and apoptosis assay kit were purchased from Thermo Fisher Scientific, Inc (Waltham, MA, USA). A luciferase assay system and TPA were purchased from Promega (Madison, WI, USA). All other antibodies were purchased from Santa Cruz Biotechnology, Inc. (Santa Cruz, CA, USA).

Preparation of the heavy metal mixture. The mixture of heavy metals used in the present study comprised eight heavy metals commonly contaminating the surface waters in the Ningbo region, including zinc, manganese, lead, copper, cadmium, mercury, chromium, and nickel. The proportions of these eight heavy metal ions in the offshore water were determined according to previous reports $(20,21)$. The chemical compounds were dissolved in DMEM to prepare the stock solution (Table I). The final concentration of the stock solution (total of the eight heavy metal ions) was $25.233 \mathrm{mg} / 1$. The stock solution was diluted in DMEM at concentrations of $2.523,5047,7.570,10.093,12.617,15.140$ and $17.663 \mathrm{mg} / \mathrm{l}$, respectively, to form working solutions of the multi-heavy metal mixture.

Cell culture. JB6 cells (a mouse epidermal cell line) were provided by the National Institute of Occupational Safety and Health (Morgantown, WV, USA) were cultured in $10 \%$ NCS DMEM supplemented with penicillin-streptomycin $\left(10,000 \mathrm{U} / \mathrm{ml}\right.$ penicillin and $10 \mathrm{mg} / \mathrm{ml}$ streptomycin) at $37^{\circ} \mathrm{C}$ (80\% humidified air and $5 \% \mathrm{CO}_{2}$ ).

Cytotoxicity assay. The toxicity of the multi-heavy metal mixture towards the JB6 cells was assessed using an MTT assay. Briefly, the cells were plated in $180 \mu \mathrm{l}$ DMEM at a density of $0.5 \times 10^{4}$ cells/well in a 96 -well plate. The cells were treated with the various concentrations of the multi-heavy metal mixture and cultured for $24 \mathrm{~h}$ at $37^{\circ} \mathrm{C}$. After $24 \mathrm{~h}, 20 \mu \mathrm{l}$ MTT labeling reagent was added in each well and the plates were incubated for a further $4 \mathrm{~h}$ at $37^{\circ} \mathrm{C}$. Subsequently, $150 \mu \mathrm{l}$ solubilization solution was added to each well and the plate was incubated for $10 \mathrm{~min}$ at $37^{\circ} \mathrm{C}$. The optical density of each well was measured at a wavelength of $490 \mathrm{~nm}$ using an ELISA plate reader.

Cell cycle detection. The JB6 cells were seeded onto a 6 -well plate overnight in $2 \mathrm{ml}$ DMEM at a density of $2 \times 10^{5}$ cells/well (22). The cells were then treated with or without the various concentrations of the multi-heavy metal mixture for $24 \mathrm{~h}$. The cells were harvested using $0.1 \%$ trypsin and fixed overnight in a pre-cooling $70 \%$ ethanol at $-20^{\circ} \mathrm{C}$. The fixed cells were subsequently centrifuged at $10,000 \mathrm{x} \mathrm{g}$ for $30 \mathrm{~min}$ at $4^{\circ} \mathrm{C}$, resuspended in PBS and stained with $0.02 \mathrm{mg} / \mathrm{ml}$ PI for $30 \mathrm{~min}$ in the dark. The population of cells in each phase was then determined using flow cytometry (Bio-Rad Laboratories, Inc., Hercules, CA, USA).

Identification of cell apoptosis. Double staining with Annexin V-FITC (apoptotic cell marker) and PI (nuclear marker) was used to determine whether the cell death induced by the multi-heavy metal mixture was apoptotic. As stated above, the JB6 cells were seeded onto a 6-well plate and incubated overnight, and were treated with or without the various concentrations of the multi-heavy metal mixture for $24 \mathrm{~h}$. The cells were then harvested using $0.1 \%$ trypsin and were washed twice with cold PBS. Annexin V-FITC (5 $\mu 1)$ and PI (1 $\mu \mathrm{l})$ were added to the cultures, and the cells were incubated in the dark for $15 \mathrm{~min}$ at $25^{\circ} \mathrm{C}$. Cell apoptosis was analyzed using flow cytometry (Bio-Rad Laboratories, Inc.) within $1 \mathrm{~h}$.

ROS detection. $\mathrm{H}_{2} \mathrm{DCFDA}$ and $\mathrm{DHE}$ are used for general ROS and oxygen radical staining in cells, respectively. In the present study, the cells $\left(2.0 \times 10^{5}\right.$ cells in $2 \mathrm{ml} \mathrm{DMEM} /$ well $)$ were seeded in a 6-well plate overnight, following which they were treated with or without the various concentrations of 


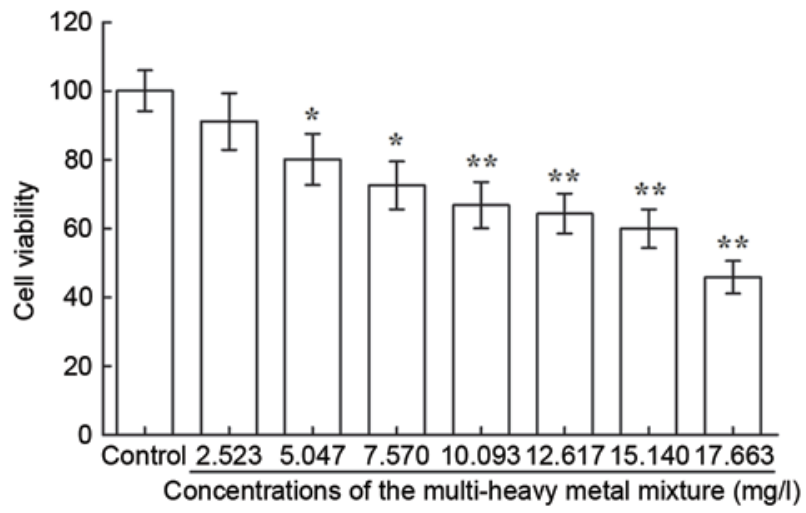

Figure 1. Cell viability following treatment of JB6 cells with or without the multi-heavy metal mixture. ${ }^{*} \mathrm{P}<0.05$ and ${ }^{* *} \mathrm{P}<0.01$, compared with the control.

the multi-heavy metal mixture. The cells were fixed in $95 \%$ ethanol for $5 \mathrm{~min}$ and then washed twice with PBS. The cells were then incubated in PBS in the presence of $\mathrm{H}_{2}$ DCFDA $(5 \mu \mathrm{M})$, DHE $(2 \mu \mathrm{M})$ and Hoechst $33342(3 \mu \mathrm{M})$ for $1 \mathrm{~h}$ at $37^{\circ} \mathrm{C}$. Following incubation, the cells were washed three times with PBS and images of ROS generation in cells were captured using fluorescence microscopy (Axiovert 100M; Zeiss GmbH, Jena, Germany).

Luciferase assay. The JB6 cells transfected with the nuclear transcription factors $\mathrm{AP}-1$ or $\mathrm{NF}-\kappa \mathrm{B}$ (provided by the National Institute of Occupational Safety and Health) were used to detect the luciferase activities of AP-1 or $\mathrm{NF}-\kappa \mathrm{B}$. A cell suspension $\left(2 \mathrm{ml} ; 1 \times 10^{5}\right.$ cells $\left./ \mathrm{ml}\right)$ was seeded in a 24-well plate in $10 \%$ NCS DMEM and incubated at standard culture conditions $\left(37^{\circ} \mathrm{C}, 80 \%\right.$ humidified air and $\left.5 \% \mathrm{CO}_{2}\right)$ for $24 \mathrm{~h}$. The cultures were then starved in $0.1 \%$ NCS DMEM overnight. The cells were treated with or without the various concentrations of the multi-heavy metal mixture for $8 \mathrm{~h}$ in $10 \%$ NCS DMEM. Following two washes with PBS, $120 \mu \mathrm{l}$ of $1 \mathrm{X}$ Promage lysate buffer was added to each well. Following incubation on ice for $60 \mathrm{~min}$, the lysate was centrifuged at $12,000 \mathrm{x} \mathrm{g}$ for $20 \mathrm{~min}$ at $4^{\circ} \mathrm{C}$ to obtain the supernatant. Luciferase activity was measured using a luciferase assay kit according to the manufacturer's protocol. TPA (20 nM) was used as a positive control for the upregulation of AP-1 or $\mathrm{NF}-\kappa \mathrm{B}$ luciferase activity.

Western blot analysis. The cells $\left(5 \times 10^{4}\right.$ cells in $1 \mathrm{ml}$ of culture medium) were plated into a 6-well plate and incubated overnight. The cultures were treated with or without the various concentrations of the multi-heavy metal mixture for $8 \mathrm{~h}$. To collect the cell pellet, the cells were centrifuged at $12,000 \mathrm{x} \mathrm{g}$ for $5 \mathrm{~min}$ at $4^{\circ} \mathrm{C}$ following which the cells were lysed in $100 \mu \mathrm{l}$ of NP40 lysate supplemented with a protease inhibitor cocktail. Following incubation on ice for $60 \mathrm{~min}$, the cell suspension was centrifuged at $12,000 \times \mathrm{g}$ for $20 \mathrm{~min}$ at $4^{\circ} \mathrm{C}$ to obtain the supernatant. The protein concentrations in the supernatants were determined using the BCA protein quantitative method. Equal quantities of proteins $(50 \mu \mathrm{g})$ were denatured for $5 \mathrm{~min}$ at $95^{\circ} \mathrm{C}$, electrophoresed by $10 \%$ SDS-PAGE, and transferred onto PVDF membranes. After proteins were transferred, Ponceau $\mathrm{S}$ dye was used indicate protein transfer. Initially, the blots were blocked in $5 \%$ milk blocking buffer for $3 \mathrm{~h}$ and then incubated overnight at $4^{\circ} \mathrm{C}$ with the primary antibody. C-jun and p65 antibodies (Cell signaling Technologies, Inc., Danvers, MA, USA; cat. nos. 1694 and 372, respectively) were diluted in 5\% milk blocking buffer at 1:1,000 and $\beta$-actin antibody (Beyotime Institute of Biotechnology, Shanghai, China; cat. no. AF0003) at 1:10,000. Then, after washing with TBST, the blots were incubated for $2 \mathrm{~h}$ at room temperature with the IgH horseradish peroxidase-conjugated secondary antibody (Boster Biological Engineering Co. Ltd., Wuhan, China; cat. no. BA1054) at 1:1,000. Finally, the chemiluminescence of proteins transferred onto PVDF membranes were detected with ECL Plus (Asvansta Inc., Menlo Park, CA, USA). Then the images of the blots were captured using Bio-Rad image capture system (Bio-Rad Laboratories, Inc.) and Quantity One v.465 software (Bio-Rad Laboratories, Inc.) was used for band analysis.

Statistical analysis. The experiments were repeated at least three times and data are presented as the mean \pm standard deviation. Significant differences were determined using SAS 9.1 software (SAS Institute, Inc., Cary, NC, USA) or one-way analysis of variance. $\mathrm{P} \leq 0.05$ was considered to indicate a statistically significant difference.

\section{Results}

Cytotoxicity. The results of the MTT assay (Fig. 1) and cell morphological observation under the microscope (Fig. 2) showed that the multi-heavy metal mixture induced dose-dependent cytotoxicity in the JB6 cells.

Cell cycle detection. The histograms in Fig. 3A show cell cycle distribution, detected using flow cytometry. Further analysis indicated that, as the concentration of the multi-heavy metal mixture increased, the number of cells arrested at the $\mathrm{S}$ phase

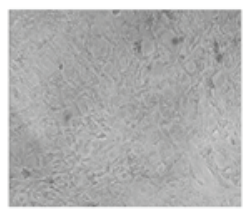

Control

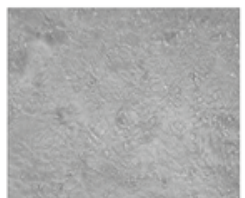

2.523

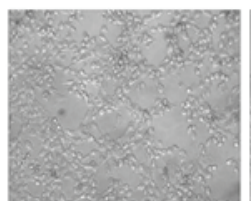

10.093

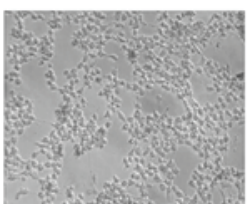

17.663

Concentrations of the multi-heavy metal mixture $(\mathrm{mg} / \mathrm{l})$

Figure 2. Morphology of JB6 cells following treatment with or without the multi-heavy metal mixture. Under higher concentrations (10.093 and 17.663 mg/l), the JB6 cell number gradually decreased and began to shrink in shape (magnification $\mathrm{x} 20$ ). 

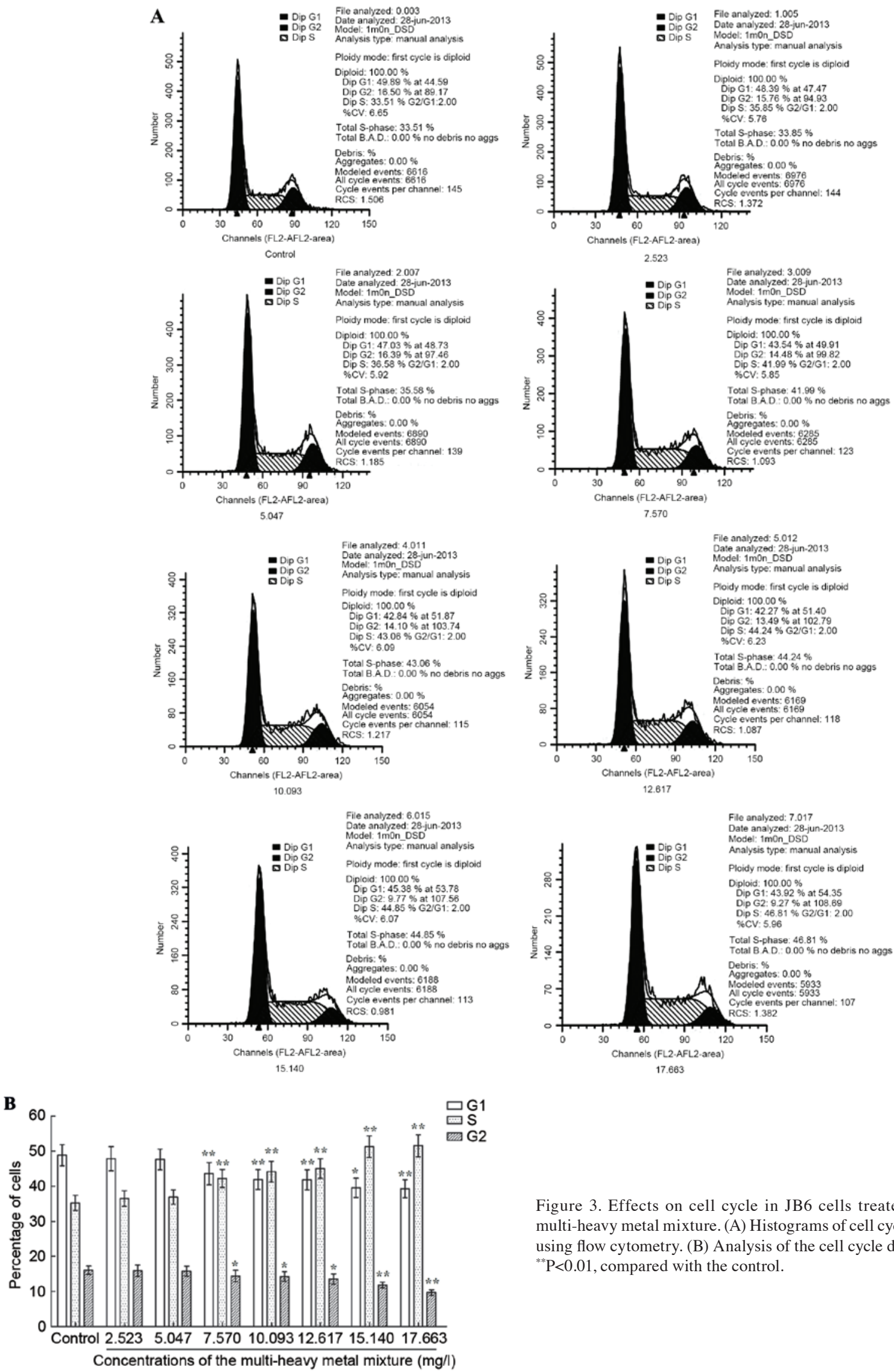

Figure 3. Effects on cell cycle in JB6 cells treated with or without the multi-heavy metal mixture. (A) Histograms of cell cycle distribution detected using flow cytometry. (B) Analysis of the cell cycle distribution. ${ }^{*} \mathrm{P}<0.05$ and ${ }^{* *} \mathrm{P}<0.01$, compared with the control.

increased, which was accompanied by a decrease in the number of cells at the G1 and G2 phases. These results were found to be dose-dependent (Fig. 3B; Table II).
Cell apoptosis induction. Following treatment with or without different concentrations of the multi-heavy metal mixture for 24 h, double staining with Annexin V-FITC and PI (Fig. 4A) 
Table II. Effects of the multi-heavy metal mixture on the cell cycle of JB6 cells.

Concentration of

Phase of cell cycle (\%)

mixture (mg/l)

\begin{tabular}{ccc}
\hline $\mathrm{G} 1$ & $\mathrm{~S}$ & $\mathrm{G} 2$ \\
\hline $48.74 \pm 0.76$ & $35.20 \pm 1.49$ & $16.05 \pm 1.00$ \\
$47.76 \pm 0.81$ & $36.39 \pm 2.18$ & $15.86 \pm 1.45$ \\
$47.49 \pm 1.39$ & $36.79 \pm 0.82$ & $15.73 \pm 0.57$ \\
$43.34 \pm 0.68^{\mathrm{b}}$ & $42.17 \pm 0.65^{\mathrm{b}}$ & $14.49 \pm 0.03^{\mathrm{a}}$ \\
$41.66 \pm 1.21^{\mathrm{b}}$ & $44.04 \pm 0.96^{\mathrm{b}}$ & $14.30 \pm 0.65^{\mathrm{a}}$ \\
$41.65 \pm 0.88^{\mathrm{b}}$ & $44.91 \pm 0.95^{\mathrm{b}}$ & $13.44 \pm 0.07^{\mathrm{a}}$ \\
$39.23 \pm 0.22^{\mathrm{a}}$ & $51.21 \pm 0.50^{\mathrm{b}}$ & $9.57 \pm 0.28^{\mathrm{b}}$ \\
$39.09 \pm 0.71^{\mathrm{b}}$ & $51.53 \pm 0.79^{\mathrm{b}}$ & $9.38 \pm 0.16^{\mathrm{b}}$
\end{tabular}

0 (control)

2.523

5.047

$47.76 \pm 0.81$

$35.20 \pm 1.49$

$16.05 \pm 1.00$

7.570

$47.49 \pm 1.39$

$36.79 \pm 0.82$

$15.73 \pm 0.57$

10.093

$43.34 \pm 0.68$

$42.17 \pm 0.65$

$14.49 \pm 0.03^{a}$

12.617

$41.66 \pm 1.21$

$44.04 \pm 0.96$

$14.30 \pm 0.65^{\circ}$

15.140

$39.23 \pm 0.22^{a}$

$51.53 \pm 0.79^{\mathrm{b}}$

$9.38 \pm 0.16^{\mathrm{b}}$

Cell cycle data are presented as the mean \pm standard deviation. ${ }^{a} \mathrm{P}<0.05$ and ${ }^{\mathrm{b}} \mathrm{P}<0.01$, compared with the control.

A

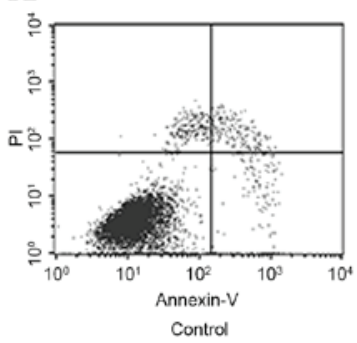

Quad \% Gated X mean $Y$ mean

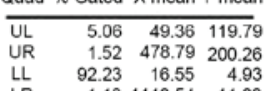

$\begin{array}{lrrr}\text { LL } & 92.23 & 16.55 & 4.93 \\ \text { LR } & 1.18 & 1110.54 & 11.00\end{array}$
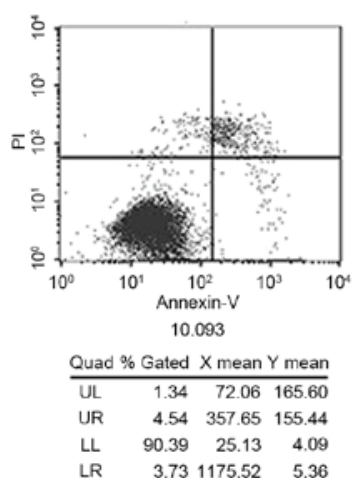

\section{B}

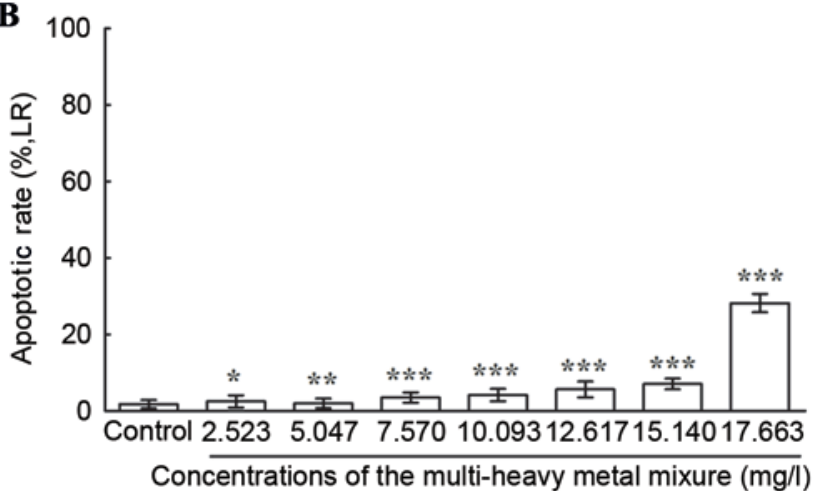

showed that the multi-heavy metal mixture induced JB6 cell apoptosis in a dose-dependent manner (Fig. 4B).
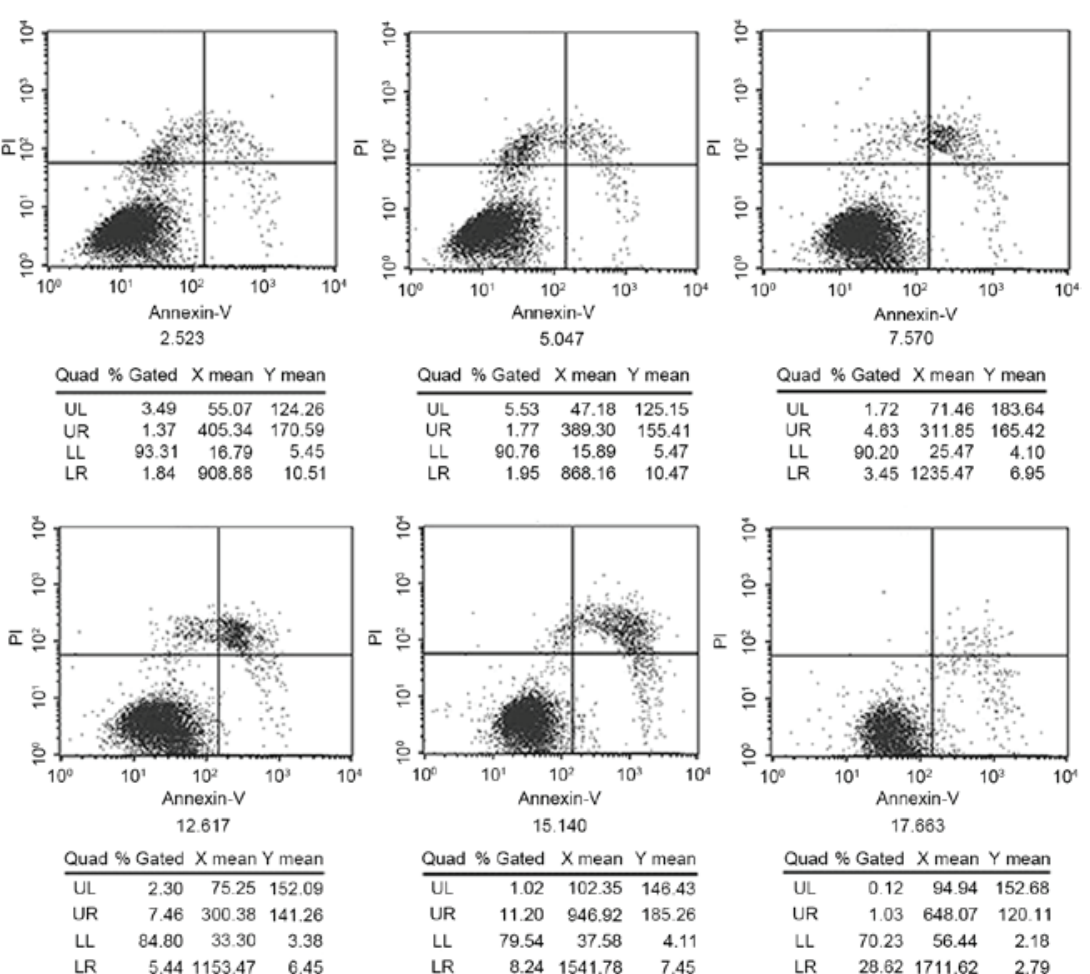

Figure 4. Cell apoptosis detected using flow cytometry. (A) UL quadrant $\left(\mathrm{PI}^{+} / A n n e x i n \mathrm{~V}^{-}\right)$represents mechanical damage of cells; LL quadrant $\left(\mathrm{PI}^{-} /\right.$Annexin $\left.\mathrm{V}^{-}\right)$represents normal cells; UR quadrant $\left(\mathrm{PI}^{+} /\right.$Annexin $\left.\mathrm{V}^{+}\right)$ represents late apoptotic or necrotic cells; LR quadrant $\left(\mathrm{PI}^{-} / \mathrm{Ann}\right.$ exin $\left.\mathrm{V}^{+}\right)$ represents early apoptotic cells. (B) Early apoptotic cell numbers induced under exposure to different concentrations of the multi-heavy metal mixture in JB6 cells. ${ }^{*} \mathrm{P}<0.05,{ }^{* *} \mathrm{P}<0.01$ and ${ }^{* * *} \mathrm{P}<0.001$, compared with the control. PI, propidium iodide; UL, upper left; LL, lower left; UR, upper right; LR, lower right.
ROS generation. The results of the present study showed that higher doses of the multi-heavy metal mixture induced 

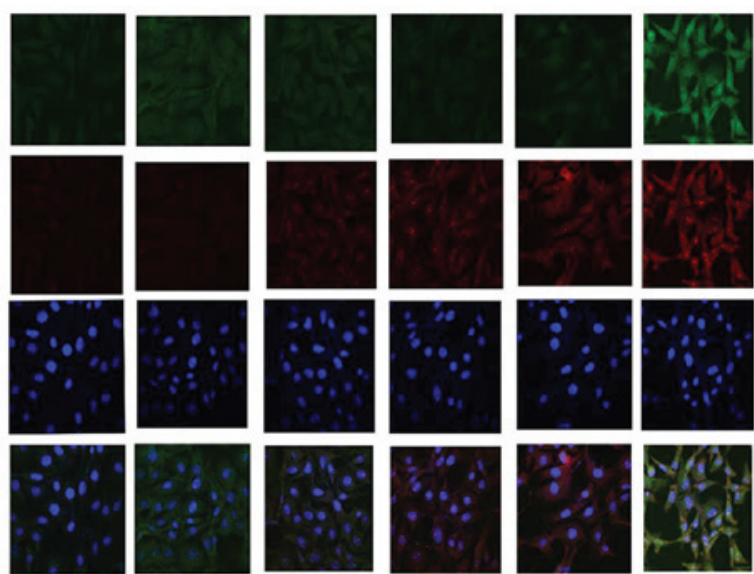

Control 2.523
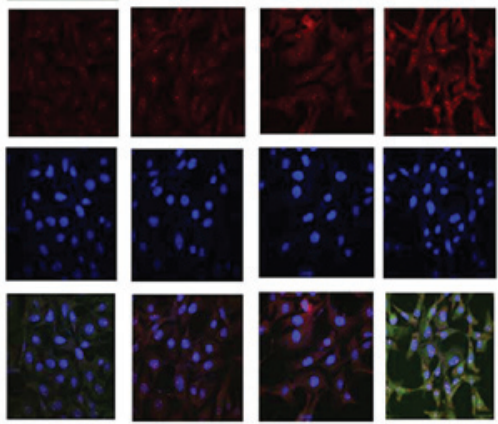

10.093
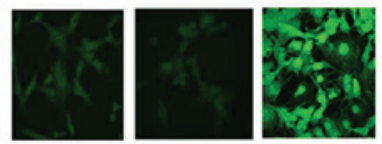

$\mathrm{H}_{2}$ DCFDA
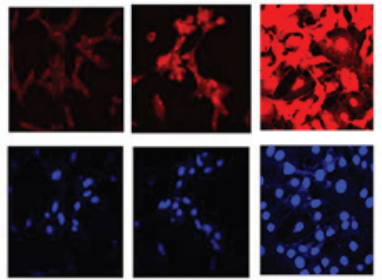

Hoechst
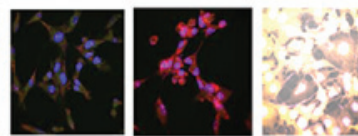

Merge

Concentrations of the multi-heavy metal mixture $(\mathrm{mg} / \mathrm{l}) \frac{\mathrm{s}}{500 \mu \mathrm{M}}$

Figure 5. Induction of ROS generation in JB6 cells by the multi-heavy metal mixture. ROS were detected via $\mathrm{H}_{2} \mathrm{DCFDA}$ (green) and DHE staining (red). Nuclei were stained using Hoechst dye. $\mathrm{H}_{2} \mathrm{O}_{2}(500 \mu \mathrm{M})$ was set as a positive control to induce ROS generation. ROS, reactive oxygen species; $\mathrm{H}_{2}$ DCFDA, 7'-dichlorodihydrofluorescein diacetate; DHE, dihydroethidium.
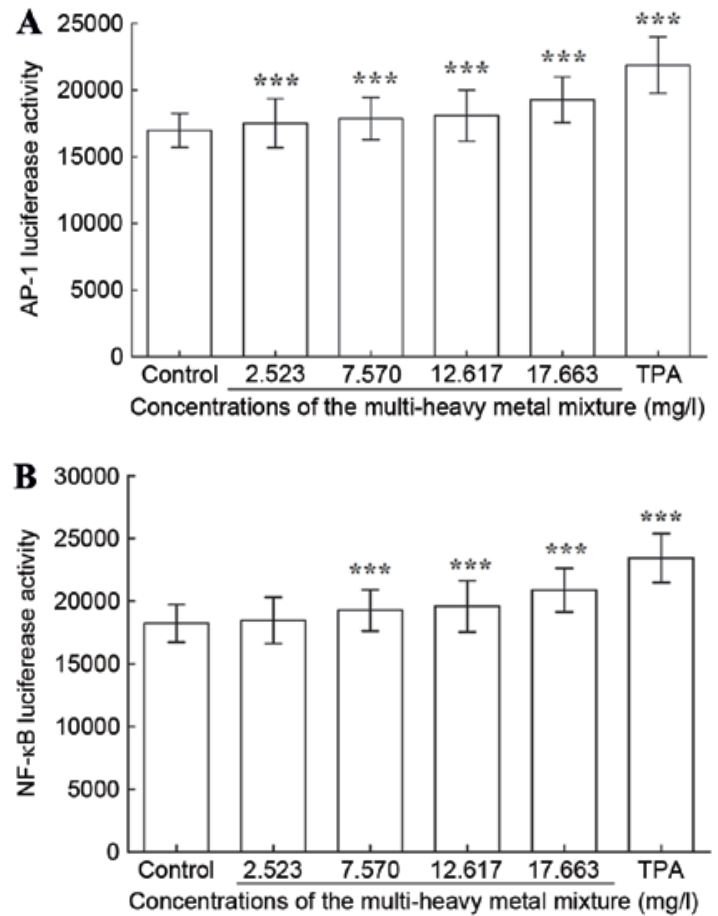

Figure 6. Effects of the multi-heavy metal mixture on the luciferase activities of (A) AP-1 and (B) NF-кB in JB6 cells. ${ }^{* * *} \mathrm{P}<0.05$, compared with the control. AP-1, activator protein-1; NF- $\kappa \mathrm{B}$, nuclear factor- $\kappa \mathrm{B}$.

significant ROS generation (Fig. 5).

Luciferase activities of $A P-1$ and $N F-\kappa B$. The results demonstrated that the multi-heavy metal mixture induced upregulation in the luciferase activities of AP-1 (Fig. 6A) and $\mathrm{NF}-\kappa \mathrm{B}$ (Fig. 6B) in a dose-dependent manner.

Expression of cell signaling proteins. The results of the western blot analysis showed that the multi-heavy metal mixture induced an upregulation in cell signaling protein expressions of C-jun and p65 (Fig. 7).

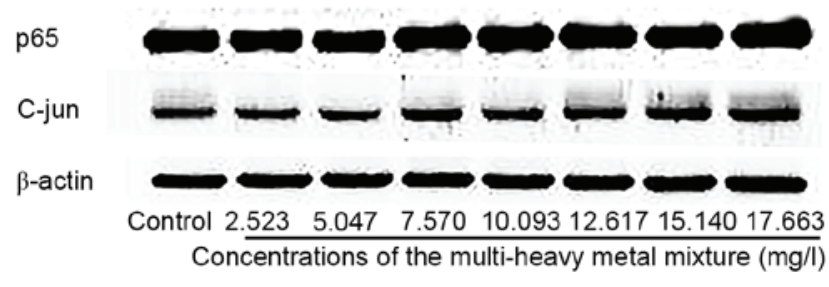

Figure 7. Effects of the multi-heavy metal mixture on the expression of cell signaling proteins in JB6 cells.

\section{Discussion}

In the past 30 years, China has experienced a rapidly developing economy, which has led to serious environmental pollution. Among the different types of pollution, heavy metal pollution has become one of the major environmental issues (23). In China, coastal areas are under increased threat due to heavy metal contamination caused by an increase in urbanization and industrialization, compared with inland areas. Evidence indicates that the heavy metals present in certain seafood from coastal areas may exceed the safety limit, caused by heavy metal contamination in the surface water (24). The contamination of heavy metals in the water in the coastal area is considered to be a threat to marine farming and human health in China. The toxicities of single heavy metals, including lead and nickel, have been well documented (25). However, in daily life, individuals are usually exposed to a contamination by multiple heavy metals simultaneously from water (26), the air or food consumption. To investigate the joint toxicity and the underlying mechanisms of multi-heavy metal exposure, the present study selected eight heavy metals commonly found contaminating the offshore waters of the Ningbo region, and prepared a mixture with the proportions of each contaminant matching those in the region.

In China, although different regions have different spectrums in heavy metal contamination, $\mathrm{Zn}, \mathrm{Pb}, \mathrm{Cu}$ and $\mathrm{Cd}$ remain the dominant contaminations whether in the water or 
soil (27), which is similar to the contamination spectrum of the offshore water in the Ningbo region (Table II). Although heavy metals, including $\mathrm{Zn}$ and $\mathrm{Cu}$, are essential elements in the human body, exposure to high doses can also be harmful to human health, particularly when combined with other toxic heavy metals.

Detecting levels of cytotoxicity provides an economical method for evaluating the toxicity of compounds. In the present study, it was found that the mixture of eight common heavy metals induced cytotoxicity in the JB6 cells in a dose-dependent manner. The cause underlying the cytotoxic effect of heavy metals remains to be fully elucidated, however, it has been suggested that their toxicity, at least in part, may be due to the formation of hydroxyl radicals, which can lead to lipid, protein or DNA damage (28). In the present study, it was found that the multi-heavy metal mixture induced significant ROS generation and cell apoptosis. Exposure to the mixture exposure also arrested the JB6 cells at the S phase, indicated by an increase in the proportion of cells in the $\mathrm{S}$ phase from $35.2 \%$ in the control to $51.53 \%$ (17.663 mg/l), and a decrease in the proportion of cells in the G2 phase from $16.05 \%$ in the control to $9.35 \%$ (17.663 mg/l). Evidence shows that different heavy metals can exert different effects on the cell cycle. A significant increase of intracellular $\mathrm{Zn}$ content in MDAMB231 cells results in G1 and G2/M cell cycle arrest, and cell apoptosis (29). Manganese chloride induces G0/G1 phase arrest and apoptosis in cultured rat astrocytes (30). Sub-lethal exposure of Swiss albino mice to copper, as copper chloride, induces an increase in G0/ G1 cell numbers in the thymus and spleen (31). Cadmium can induce a delay in the transition between the G1 and S phases of the cell cycle, and slows progression through the $\mathrm{S}$ phase (28). Nickel (II) modulates cellular responses through effectors involved in $\mathrm{G} 2 / \mathrm{M}$ arrest and apoptosis regulatory pathways $(32,33)$. Rodríguez-Sastre et al (34) evaluated the capability of a mixture of $2 \mu \mathrm{M} \mathrm{NaAsO}_{2}, 2 \mu \mathrm{M} \mathrm{CdCl}_{2}$ and $5 \mu \mathrm{M}$ $\mathrm{Pb}\left(\mathrm{C}_{2} \mathrm{H}_{3} \mathrm{O}_{2}\right)_{2} \cdot 3 \mathrm{H}_{2} \mathrm{O}$ at relevant epidemiological concentrations to induce cell transformation processes. The results revealed a decrease in cell viability and an increase in ROS, accompanied by $\mathrm{G} 1$ cell cycle arrest. Costa et al (35) found that 1-6 $\mu \mathrm{M}$ of $\mathrm{CdCl}_{2}, \mathrm{HgCl}_{2}, \mathrm{CoCl}_{2}, \mathrm{CuSO}_{4}, \mathrm{NiCl}_{2}, \mathrm{ZnCl}_{2}$ and $\mathrm{PbSO}_{4}$ slowed cell growth and selectively arrested cells in the $\mathrm{S}$ phase. It was concluded that the potency of the metal compounds in arresting cells in the $\mathrm{S}$ phase was associated with their chemical reactivity and uptake into cells. Specifically, the $S$ phase arrest produced by the metals examined was consistent with their genotoxic or carcinogenic activities; as such activity indicated a selective interaction with DNA metabolism. In the present study, $\mathrm{H}_{2}$ DCFDA and DHE were used for the staining of general ROS and oxygen radicals produced in JB6 cells, respectively (36). It was found that treatment of cells with the multi-heavy metal mixture induced significant ROS generation followed by apoptosis of the JB6 cells. It is known that ROS can damage DNA (37). DNA damage can cause $S$ phase arrest in the cell and switch on cell apoptotic pathways. The detailed mechanism underlying the effects of the multi-heavy metal mixture on inducing the combined toxic effects of $\mathrm{S}$ phase arrest in the cell requires further investigation.

The AP-1 transcription factor family consists of the subfamilies, C-jun, C-fos, activating transcription factor and Jun dimerization partners. AP-1 family members can induce physiological or pathological responses under certain stimulation, including stress, radiation or growth signals, and are involved in processes, including cell proliferation, differentiation and transformation, which are important in tumor formation, metastasis and invasion. The activation of AP-1 can directly regulate the expression of several cancer genes. $\mathrm{C}$-jun, as one of the subunits of the AP-1 transcriptional regulatory protein family, can react to a variety of stimuli (38). An increase of C-jun can increase the risk of cancer $(39,40)$. The NF- $\kappa \mathrm{B}$ transcription factor is a particularly broad inducible transcription factor $(41,42)$. Similar to $A P-1, N F-\kappa B$ is also important in immunity, inflammation, cell survival, proliferation, differentiation and apoptosis (43-45). p65 is a subunit of NF- $\kappa \mathrm{B}$ and the activation of p65 is associated with carcinogenesis (46-48). In the present study, it was found that the multi-heavy metal mixture induced an upregulation in the luciferase activities of $\mathrm{AP}-1$ and $\mathrm{NF}-\kappa \mathrm{B}$, and the protein levels of $\mathrm{C}$-jun and p65 in a dose-dependent manner. These results suggested that multi-heavy metal exposure at a high concentration for a prolonged duration may be carcinogenetic.

In conclusion, the joint toxicities of the mixture of eight heavy metals included intercellular ROS generation, apoptosis and cell cycle arrest at the $\mathrm{S}$ phase. The AP-1 and NF- $\kappa \mathrm{B}$ transcription factors, and the protein levels of $\mathrm{C}$-jun and $\mathrm{p} 65$ were upregulated, suggesting carcinogenesis as a result of the multi-heavy metal exposure. Intercellular ROS generation may be an important effect induced by the joint toxicity of the multi-heavy metal mixture. To the best of our knowledge, this is the first study demonstrating the joint toxicities of an eight heavy metal mixture, which comprised of eight heavy metals commonly contaminating the surface waters in the Ningbo region. These results will be of benefit for elucidating the combined toxicity and the underlying mechanisms of multi-heavy metal pollution. In addition, the result may also be useful as a reference when examining the toxicity of multi-heavy metal pollutants in aquatic products in further studies.

\section{Acknowledgements}

The authors would like to thank Ms. Linda Bowman (National Institute of Occupational Safety and Health, Morgantown, WV, USA) for her assistance in manuscript preparation and the KC Wong Magna Fund in Ningbo University, Hong Kong, for their support. This study was partly supported by the National Nature Science Foundation of China (grant no. 81273111), the Ningbo Scientific Project (grant no. 2012C5019), the Science Technology Department of Zhejiang Province (grant nos. 2015C33148 and 2015C37117) and the Scientific Innovation Team Project of Ningbo (grant no. 2011B82014).

\section{References}

1. Xu X, Li Y, Wang Y and Wang Y: Assessment of toxic interactions of heavy metals in multi-component mixtures using sea urchin embryo-larval bioassay. Toxicol In Vitro 25: 294-300, 2011.

2. Xie LH and Xu ZR: The toxicity of heavy metal Cadmium to animals and humans. Acta Agriculture Zhejiangensis 15: 376-381, 2003 (In Chinese). 
3. Neuberger JS, Mulhall M, Pomatto MC, Sheverbush J and Hassanein RS: Health problems in Galena, Kansas: A heavy metal mining Superfund site. Sci Total Environ 94: 261-272, 1990.

4. Evans DH and Weingarten K: The effect of cadmium and other metals on vascular smooth muscle of the dogfish shark, Squalus acanthias. Toxicology 61: 275-281, 1990.

5. Holécyová A and Török J: The effect of cadmium on neuromuscular transmission in rabbit blood vessels. Bratisl Lek Listy 91: 839-843, 1990

6. Ozdem S and Oğütman Ç: The effects of short-term nifedipine treatment on responsiveness of aortic rings of cadmium-hypertensive rats. Clin Exp Hypertens 21: 423-440, 1999.

7. Perry $\mathrm{H}$ and Erlanger MW: Pressor effects of chronically feeding cadmium and lead together. Trace substances in environmental health 12: 268-275, 1978 .

8. Perry HM Jr, Erlanger MW and Perry EF: Effect of a second metal on cadmium-induced hypertension. Arch Environ Health 38: 80-85, 1983

9. Skoczyńska A, Wróbel J and Andrzejak R: Lead-cadmium interaction effect on the responsiveness of rat mesenteric vessels to norepinephrine and angiotensin II. Toxicology 162: 157-170, 2001.

10. Lock K and Janssen C: Mixture toxicity of zinc, cadmium, copper, and lead to the potworm Enchytraeus albidus. Ecotoxicol Environ Saf 52: 1-7, 2002.

11. Zhao J, Shi X, Castranova V and Ding M: Occupational toxicology of nickel and nickel compounds. J Environ Pathol Toxicol Oncol 28: 177-208, 2009.

12. Kumar Sharma R, Agrawal M and Marshall F: Heavy metal contamination of soil and vegetables in suburban areas of Varanasi, India. Ecotoxicol Environ Saf 66: 258-266, 2007.

13. Uluturhan E and Kucuksezgin F: Heavy metal contaminants in Red Pandora (Pagellus erythrinus) tissues from the Eastern Aegean Sea, Turkey. Water Res 41: 1185-1192, 2007.

14. McGeer JC, Szebedinszky C, McDonald DG and Wood CM: Effects of chronic sublethal exposure to waterborne $\mathrm{Cu}, \mathrm{Cd}$ or $\mathrm{Zn}$ in rainbow trout. 1: Iono-regulatory disturbance and metabolic costs. Aquat Toxicol 50: 231-243, 2000.

15. Jones I, Kille P and Sweeney G: Cadmium delays growth hormone expression during rainbow trout development. J Fish Biol 59: 1015-1022, 2005

16. Almeida J, Diniz Y, Marques S, Faine LA, Ribas BO, Burneiko RC and Novelli EL: The use of the oxidative stress responses as biomarkers in Nile tilapia (Oreochromis niloticus) exposed to in vivo cadmium contamination. Environ Int 27: 673-679, 2002.

17. Jiang CZ, Zhang LJ, Rong JR, Yu AF and Qi M: Survey and evaluation of heavy metal content in fresh aquatic product in Ningbo. Chinese Journal of Health Laboratory Technology 10 : 1866-1867, 2007 (In Chinese).

18. Farombi E, Adelowo O and Ajimoko Y: Biomarkers of oxidative stress and heavy metal levels as indicators of environmental pollution in African cat fish (Clarias gariepinus) from Nigeria Ogun River. Int J Environ Res Public Health 4: 158-165, 2007.

19. Cai YT: Study on ecological environment and health quality of aquatic products in sansha bay. J Fuj Fish: 49-55, 2004.

20. Zhongjie Y, Feijin K, Jianping W and Jikang S: Assessment on heavy metal contents and environment in tidal shellfish cultured area of Ningbo. Mar Envir Sci 30: 508-511, 2011.

21. Wang J, Qin Y, Sun Y, Wu J and Cheng X: The distribution and source of heavy metals in an important aquaculture sea area Xiangshan Bay. Mar Fish 27: 225-231, 2005.

22. Lü L, Liu X, Wang C, Hu F, Wang J and Huang H: Dissociation of E-cadherin/ $\beta$-catenin complex by MG132 and bortezomib enhances CDDP induced cell death in oral cancer SCC-25 cells. Toxicol In Vitro 29: 1965-1976, 2015.

23. Hui H, Qian J and Kavan P: A study of heavy metal pollution in China: Current status, pollution-control policies and countermeasures. Sustainability 6: 5820-5838, 2014.

24. Wang SL, Xu XR, Sun YX, Liu JL and Li HB: Heavy metal pollution in coastal areas of South China: A review. Mar Pollut Bull 76: 7-15, 2013.

25. Ip CC, Li XD, Zhang G, Wong CS and Zhang WL: Heavy metal and $\mathrm{Pb}$ isotopic compositions of aquatic organisms in the Pearl River Estuary, South China. Environ Pollut 138: 494-504, 2005.

26. Morcillo P, Cordero H, Meseguer J, Esteban MÁ and Cuesta A Toxicological in vitro effects of heavy metals on gilthead seabream (Sparus aurata L.) head-kidney leucocytes. Toxicol In Vitro 30: 412-420, 2015.
27. Chen S: Heavy metal pollution in the water environment and countermeasures in China. Journal of Zhangzhou Vocational College: 54, 2002 (In Chinese).

28. Yen JL, Su NY and Kaiser P: The yeast ubiquitin ligase SCFMet30 regulates heavy metal response. Mol Biol Cell 16: 1872-1882, 2005.

29. Wang YH, Li KJ, Mao L, Hu X, Zhao WJ, Hu A, Lian HZ and Zheng WJ: Effects of exogenous zinc on cell cycle, apoptosis and viability of MDAMB231, HepG2 and 293 T cells. Biol Trace Elem Res 154: 418-426, 2013

30. Deng Y, Xu D, Xu B, Xu Z, Tian Y, Feng W, Liu W and Yang H: G0/G1 phase arrest and apoptosis induced by manganese chloride on cultured rat astrocytes and protective effects of riluzole. Biol Trace Elem Res 144: 832-842, 2011.

31. Mitra S, Keswani T, Dey M, Bhattacharya S, Sarkar S, Goswami S, Ghosh N, Dutta A and Bhattacharyya A: Copper-induced immunotoxicity involves cell cycle arrest and cell death in the spleen and thymus. Toxicology 293: 78-88, 2012.

32. Shiao YH, Lee SH and Kasprzak KS: Cell cycle arrest, apoptosis and p53 expression in nickel(II) acetate-treated Chinese hamster ovary cells. Carcinogenesis 19: 1203-1207, 1998.

33. de Lima EM, Kanunfre CC, de Andrade LF, Granato D and Rosso ND: Cytotoxic effect of inositol hexaphosphate and its $\mathrm{Ni}(\mathrm{II})$ complex on human acute leukemia Jurkat T cells. Toxicol In Vitro 29: 2081-2088, 2015

34. Rodriguez-Sastre MA, Rojas E and Valverde M: Assessing the impact of As-Cd-Pb metal mixture on cell transformation by two-stage Balb/c 3T3 cell assay. Mutagenesis 29: 251-257, 2014.

35. Costa M, Cantoni O, de Mars M and Swartzendruber DE: Toxic metals produce an S-phase-specific cell cycle block. Res Commun Chem Pathol Pharmacol 38: 405-419, 1982.

36. Zhao J, Bowman L, Magaye R, Leonard SS, Castranova V and Ding M: Apoptosis induced by tungsten carbide-cobalt nanoparticles in JB6 cells involves ROS generation through both extrinsic and intrinsic apoptosis pathways. Int J Oncol 42: 1349-1359, 2013

37. Zhu Y, Gu YX, Mo JJ, Shi JY, Qiao SC and Lai HC: $\mathrm{N}$-acetyl cysteine protects human oral keratinocytes from Bis-GMA-induced apoptosis and cell cycle arrest by inhibiting reactive oxygen species-mediated mitochondrial dysfunction and the PI3K/Akt pathway. Toxicol In Vitro 29: 2089-2101, 2015.

38. Angel P and Karin M: The role of Jun, Fos and the AP-1 complex in cell-proliferation and transformation. Biochim Biophys Acta 1072: 129-157, 1991

39. Lee W, Mitchell P and Tjian R: Purified transcription factor AP-1 interacts with TPA-inducible enhancer elements. Cell 49: 741-752, 1987

40. Karin M, Liu Zg and Zandi E: AP-1 function and regulation. Curr Opin Cell Biol 9: 240-246, 1997.

41. Hayden MS and Ghosh S: Shared principles in NF-kappaB signaling. Cell 132: 344-362, 2008.

42. Oeckinghaus A, Hayden MS and Ghosh S: Crosstalk in NF- $\kappa \mathrm{B}$ signaling pathways. Nat Immunol 12: 695-708, 2011

43. Medzhitov R: Origin and physiological roles of inflammation. Nature 454: 428-435, 2008.

44. Bhakar AL, Tannis LL, Zeindler C, Russo MP, Jobin C, Park DS MacPherson S and Barker PA: Constitutive nuclear factor-kappaB activity is required for central neuron survival. J Neurosci 22: 8466-8475, 2002.

45. Nawata R, Yujiri T, Nakamura Y, Ariyoshi K, Takahashi T, Sato Y, Oka Y and Tanizawa Y: MEK kinase 1 mediates the antiapoptotic effect of the Bcr-Abl oncogene through NF-kappaB activation. Oncogene 22: 7774-7780, 2003.

46. Zhang L, Ye SY, Ulrich B, Chen XS, Tian YJ and Zhang XB: The relationship of NF-кB p65 protein expression with Helicobacter species infection and carcinoma of esophagus in humans. Chinese Journal of Microbiology and Immunology 27: 234-239, 2007 (In Chinese)

47. Wang W, Luo HS and Yu BP: Expression of NF-кB and c-myc protein in gastric carcinogenesis. Cancer Research on Prevention and Treatment 29: 285-287, 2002 (In Chinese).

48. Wang Q: The study on the expression of p65 in the thyroid cancer and its correlation with cell cycle. China Practical Medical 2: 26-28, 2007 (In Chinese). 